\title{
Structure and absolute configuration of acetosellin, a new polyketide from a phytotoxic strain of Cercosporella acetosella ${ }^{\dagger}$
}

\author{
Gianluca Nasini, ${ }^{\mathrm{a}, *}$ Alberto Arnone, ${ }^{\mathrm{a}}$ Gemma Assante, ${ }^{\mathrm{b}}$ Gabriele Candiani ${ }^{\mathrm{a}}$ and \\ Orso Vajna de Pava ${ }^{a}$ \\ ${ }^{a}$ Centro di Studio per le Sostanze Organiche Naturali, Dipartimento di Chimica del Politecnico, via Mancinelli 7, 20133 Milano, \\ Italy \\ ${ }^{\mathrm{b}}$ Istituto di Patologia Vegetale, Università degli Studi, via Celoria 2, 20133 Milano, Italy
}

Received 30 November 2001; revised 10 January 2002; accepted 11 January 2002

\begin{abstract}
A new yellow pigment, designated acetosellin 1, was isolated from the mycelium of Cercosporella acetosella as a reduced azaphilone metabolite. The structure of $\mathbf{1}$ was determined by spectroscopic investigations and chemical evidence. Compound $\mathbf{1}$ possesses a novel carbon skeleton that of a naphtopyrane derivative, linked to an extensively conjugated chain. The absolute configuration was determined by NOE experiments and CD correlations. (C) 2002 Elsevier Science Ltd. All rights reserved.
\end{abstract}

In the course of a program aimed to identify new bioactive compounds from phytopathogenic fungi, ${ }^{2}$ the mitosporic species Cercosporella acetosella Ell. $^{3}$ was isolated as a pathogen from leaf spots of the cosmopolitan weed Rumex acetosella $\mathrm{L}$. This paper deals with the isolation, structure elucidation and biological activities of acetosellin (1), a new pigment isolated from largescale cultures of the fungus.

The crude extract was recovered with EtOAc from potato-dextrose-agar (PDA) cultures of the strain in Roux flasks at 7 days of growth and purified by silica gel chromatography eluted with a stepwise mixture of $\mathrm{CH}_{2} \mathrm{Cl}_{2}-\mathrm{MeOH}$, followed by repeated PLC.

Acetosellin (1) was isolated as a yellow solid having $\mathrm{mp}$ $155-160^{\circ} \mathrm{C},[\alpha]_{\mathrm{D}}=+283(c 0.1, \mathrm{MeOH})$; the EIMS and CIMS of 1 showed a molecular ion at $m / z$ 394, corresponding to $\mathrm{C}_{23} \mathrm{H}_{22} \mathrm{O}_{6}$. The IR spectrum exhibited absorptions at $3400 \mathrm{~cm}^{-1}, 1750$ and $1690 \mathrm{~cm}^{-1}$ suggesting the presence of hydroxy, unsaturated lactone and carbonyl groups; the UV spectrum showed $\lambda_{\max } 210$, $230 \mathrm{sh}, 245 \mathrm{sh}$, and $340 \mathrm{~nm}$ ( $\varepsilon$ 20800, 16600, 15900, 22700).

Acetylation of $\mathbf{1}$ afforded the diacetyl derivative 2, $\mathrm{mp}$ $105-108^{\circ} \mathrm{C},[\alpha]_{\mathrm{D}}=+200\left(c 0.2, \mathrm{CHCl}_{3}\right)$ indicating the

\footnotetext{
* Corresponding author.

${ }^{\dagger}$ Secondary fungal metabolites: part 61 ; for part 60 , see Ref. 1 .
}

presence in the molecule of two $\mathrm{OH}$ groups; 1 reacted with diazomethane in $\mathrm{Et}_{2} \mathrm{O}$ to give the monomethyl ether 3, supporting that one hydroxy function is located on an aromatic ring. In addition to the resonances due to the two acetate groups, the ${ }^{13} \mathrm{C}$ NMR spectrum of 2 contained 23 signals. The $s p^{2}$ signals were assigned to the above-mentioned C-9 and C-11 carbonyl carbons and to the carbons of a pentasubstituted aromatic ring $\left({ }^{1} J_{\mathrm{C}, \mathrm{H}}=163.5 \mathrm{~Hz}\right)$ and of three disubstituted $\left({ }^{1} J_{\mathrm{C}, \mathrm{H}}=\right.$ 149-154 Hz) and one tetrasubstituted double bonds. The $s p^{3}$ signals were assigned to two methyl, to three methylene (two of them oxygen bearing), to one oxygen bearing methine and to one oxygen bearing quaternary carbons.

The ${ }^{1} \mathrm{H}$ NMR spectrum (Table 1) extended the above evidence through the appearance of one tertiary methyl group $\left(\mathrm{H}_{3}-16\right)$ which was allocated at the sole quaternary $s p^{3}$ carbon $\mathrm{C}-8$ (its protons presented a long-range $\mathrm{C}, \mathrm{H}$ coupling of $4.5 \mathrm{~Hz}$ with $\mathrm{C}-8$ ), of one aromatic proton $(\mathrm{H}-14)$, of one isolated $\mathrm{AB}$ system $\left(\mathrm{H}_{2}-1\right)$ and of two sequences such as ' $-\mathrm{C}\left(1^{\prime}\right) \mathrm{H}=\mathrm{C}\left(2^{\prime}\right) \mathrm{H}-\mathrm{C}\left(3^{\prime}\right) \mathrm{H}=\mathrm{C}\left(4^{\prime}\right) \mathrm{H}-$ $\mathrm{C}\left(5^{\prime}\right) \mathrm{H}=\mathrm{C}\left(6^{\prime}\right) \mathrm{HMe}$ and $-\mathrm{C}(4) \mathrm{H}_{2}-\mathrm{C}(3) \mathrm{HOR}-\mathrm{C}(17) \mathrm{H}_{2}-$ $\mathrm{OAc}$ in which the olefinic protons are all $\mathrm{E}$, as evidenced by the ${ }^{3} J_{\mathrm{H}, \mathrm{H}}=14.9-15.2 \mathrm{~Hz}$, and the OAc group is linked at $\mathrm{C}-17$ as $\mathrm{H}_{2}-17$ underwent a downfield shift of $\sim 0.6 \mathrm{ppm}$ by acetylation. NOE experiments carried out on compounds $\mathbf{2}$ and $\mathbf{3}$ (see Data) indicated that the aromatic $\mathrm{OH}$ group and the hexatriene chain are both ortho positioned with respect to $\mathrm{H}-14$. 
Table 1. ${ }^{1} \mathrm{H}$ NMR chemical shifts for compounds 2 and 7 in acetone- $d_{6}$

\begin{tabular}{|c|c|c|c|c|c|c|c|}
\hline \multirow{2}{*}{$\frac{\text { Proton }}{1 \mathrm{a}}$} & \multicolumn{2}{|c|}{$\mathbf{2}\left(\delta_{\mathrm{H}}, \mathrm{ppm}\right)$} & \multirow{2}{*}{$\begin{array}{c}J(\mathrm{H}, \mathrm{H})(\mathrm{Hz}) \\
17.5,3.1,1.3\end{array}$} & \multirow{2}{*}{$\begin{array}{l}\text { Proton } \\
1\end{array}$} & \multicolumn{2}{|c|}{$7\left(\delta_{\mathrm{H}}, \mathrm{ppm}\right)$} & \multirow{2}{*}{$\begin{array}{l}J(\mathrm{H}, \mathrm{H})(\mathrm{Hz}) \\
17.2\end{array}$} \\
\hline & 4.71 & ddd & & & $5.02,4.78$ & br d & \\
\hline $1 b$ & 4.44 & ddd & $17.5,3.9,3.1$ & 3 & 3.51 & $\mathrm{~m}$ & \\
\hline $4 a$ & 3.00 & dddd & $17.6,10.2,3.9,3.1$ & 11,13 & $7.17,6.95$ & $\mathrm{~d}$ & 1.8 \\
\hline $4 b$ & 2.88 & dddd & $17.6,3.1,3.1,1.3$ & 15 & 2.41 & $\mathrm{~s}$ & \\
\hline 14 & 7.38 & $\mathrm{~s}$ & & 16 & $3.70,3.68$ & $\mathrm{~m}$ & \\
\hline $17 \mathrm{~b}$ & 4.23 & $\mathrm{dd}$ & $11.9,6.0$ & $3^{\prime}$ & 6.36 & $\mathrm{~m}$ & \\
\hline $1^{\prime}$ & 7.26 & br dd & 15.2 & $4^{\prime}$ & 6.40 & $\mathrm{~m}$ & \\
\hline $2^{\prime}$ & 6.94 & br dd & $15.2,10.2$ & $5^{\prime}$ & 6.19 & $\mathrm{~m}$ & \\
\hline $3^{\prime}$ & 6.45 & br dd & $15.1,10.2$ & $6^{\prime}$ & 5.77 & $\mathrm{dq}$ & $15.0,7.0$ \\
\hline $4^{\prime}$ & 6.53 & br dd & $15.1,10.2$ & $7^{\prime}$ & 1.78 & dd & $7.0,1.8$ \\
\hline $5^{\prime}$ & 6.22 & ddq & $14.9,10.2,1.7$ & OH-9, -12 & $9.46,7.65$ & br s & \\
\hline
\end{tabular}

On catalytic hydrogenation with $10 \%$ palladium on carbon, 1 gave the hexahydroderivative $\mathbf{4}, \mathbf{M}^{+}, m / z 400$ which, in turn, afforded the expected diacetate 5; the ${ }^{1} \mathrm{H}$ NMR spectrum revealed that the reduction occurred only at the three double bonds of the side chain. The reaction of compound 1 with $\mathrm{OsO}_{4}$ and $\mathrm{KIO}_{4}$, afforded the derivative 6, which presented an aldehydic group in place of the unsaturated chain.
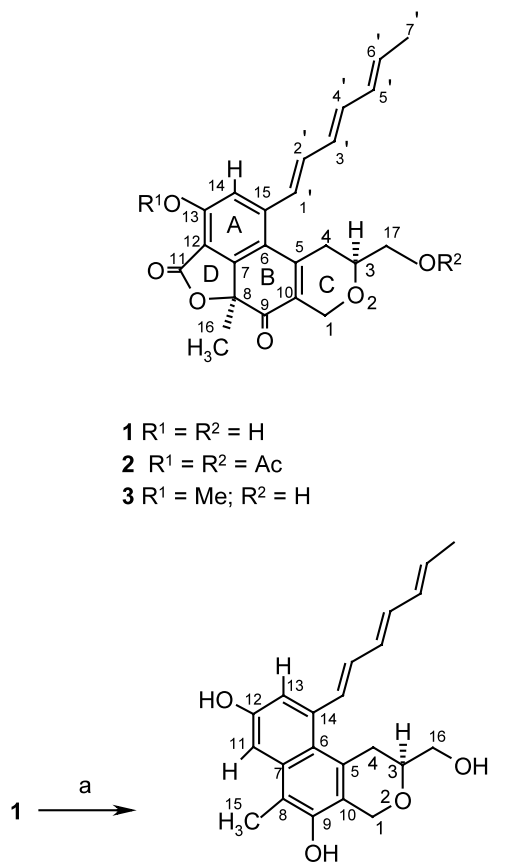

7
Further information on the structure of acetosellin followed from the reaction of 1 with $\mathrm{Zn}$ and $\mathrm{H}_{2} \mathrm{SO}_{4}$; in fact, the isolated compound 7 , which analyzed for $\mathrm{C}_{22} \mathrm{H}_{24} \mathrm{O}_{4}$, presented no carbonyl bands in the IR spectrum and showed two additional protons in the ${ }^{1} \mathrm{H}$ NMR spectrum (Table 1) attributable to one aromatic $\mathrm{OH}$ group and to one aromatic proton meta positioned with respect to $\mathrm{H}-13\left({ }^{4} J_{\mathrm{H}, \mathrm{H}}=1.8 \mathrm{~Hz}\right)$; moreover, the<smiles>[R2]C[C@H]1CC2=C(CO1)C(=O)[C@@]1(C)OC(=O)c3c([R])c([R])cc(c31)C2</smiles>

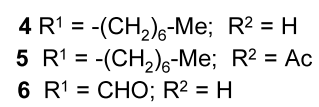<smiles>CCCCCCCC1CC(=O)Cc2c(C)c(O)c3c(c21)C[C@H](CO)OC3</smiles>

a) $\mathrm{Zn}, \mathrm{MeOH}-\mathrm{H}_{2} \mathrm{SO}_{4}(95: 5), 0.5$ hour.

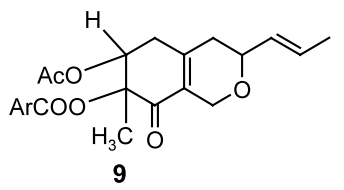


15-methyl protons resonated at $2.41 \mathrm{ppm}$ suggesting that the $\mathrm{C}(15) \mathrm{H}_{3}$ group is located on an aromatic ring. All these findings can be explained by the acidic opening of the lactone ring $\mathrm{D}$ followed by reductive decarboxylation and aromatization of the ring B to gave 7 . The same reaction made on $\mathbf{4}$ gave in good yield the major product $\mathbf{8}$ which presented the partial reduction of the aromatic ring A too; compound $\mathbf{8}$ is homogeneous but the stereochemistry of the new C-14 chiral center was not determined.

The remaining $\mathrm{C}_{4} \mathrm{H}_{8} \mathrm{O}_{2}$ fragment of compound 2 must be part of the dihydropyran ring $\mathrm{C}$ in which the $\mathrm{C}(4) \mathrm{H}_{2}$ group is linked at $\mathrm{C}-5$, since the $4-\mathrm{H}_{2}$ protons presented a mutual NOE with $\mathrm{H}^{-1}$ ' (see Data). The similarity of the aliphatic portion of acetosellin with that of wortmin 9, a metabolite isolated by us in Penicillium wortmanni, ${ }^{4}$ justified these assignments.

Finally, the mutual NOEs observed between H-3 and $\mathrm{H}_{3}-16$ in compound 2 indicated that these protons are on the same side of the molecule permitting us to assign the relative configuration of $\mathrm{C}-3$ and $\mathrm{C}-8$.

The structure 1 allows us to include acetosellin among the class of azaphilone metabolites, produced by fungi belonging to different genera: Aspergillus, Monascus, Penicillium and Chaetomium. Among azaphilones bearing a five-membered lactone ring, two types of junction are known: the linear type as in rotiorin, monascorubrin and monascoflavin, and the angular type as in rubrorotiorin, deflectins and chaetoviridins; ${ }^{5}$ acetosellin 1 evidently belongs to the first type.

The absolute configuration at C-8 of azaphilones so far known was established from CD curves; ${ }^{6}$ the sign of the Cotton effect at the longest wavelength depends on the configuration at the C-8 position. The CD of $1\left(\Delta \varepsilon_{340}=\right.$ $-10)$ clearly showed the $(S)$ configuration at C-8 and the absolute configuration of acetosellin 1 was consequently concluded to be as shown in $\mathbf{1}$. Moreover, the structure 1 is the most probable on the basis of biogenetic arguments, owing to the close similarity to others members of the azaphilone group. ${ }^{7}$ Acetosellin is as an interesting new example having a low oxidation level in the rings $\mathrm{B}$ and $\mathrm{C}$, it appears as a polyketide composed of a main chain (4 units) starting from the side chain at $\mathrm{C}_{17}$ and ending at $\mathrm{C}_{11}$ with two subsidiary chains attached at the C-7 (2 units) and C-12 (5 units).

Acetosellin (1) was tested for biological activity: it did not show any antifungal and antitumoral activity and had a weak lethal activity for Micrococcus luteus and Saccharomyces cerevisiae. Acetosellin inhibited Lepidium sativum and Zea mais in the root elongation assays ${ }^{8}$ at $6.4 \cdot 10^{-4} \mathrm{M}$, but could not be reisolated from the test solution at the end of the trial.

\section{Physical and spectroscopic data of the compounds}

1: Anal. C, 69.84\%; H, 5.69\%, calcd for $\mathrm{C}_{23} \mathrm{H}_{22} \mathrm{O}_{6}, \mathrm{C}$, $70.04 \%$; H, 5.63\%; CD ( $\left.\mathrm{MeOH}, c \mathrm{mg} / \mathrm{cm}^{3} 0.1\right): 216$,
245,271 and $340(\Delta \varepsilon+10,-1,+4,5,-10) ;{ }^{1} \mathrm{H}$ NMR acetone- $d_{6}(\delta / \mathrm{ppm}): 9.90(1 \mathrm{H}$, br signal, OH-13), 7.21 $\left(1 \mathrm{H}\right.$, br d, $\left.J=15.3 \mathrm{~Hz}, \mathrm{H}-1^{\prime}\right), 7.03(1 \mathrm{H}, \mathrm{s}, \mathrm{H}-14), 6.78$ $\left(1 \mathrm{H}\right.$, br dd, $J=15.3$ and $\left.10.1 \mathrm{~Hz}, \mathrm{H}-2^{\prime}\right), 6.47(1 \mathrm{H}$, br dd, $J=14.9$ and $\left.10.0 \mathrm{~Hz}, \mathrm{H}-4^{\prime}\right), 6.42(1 \mathrm{H}$, br dd, $J=14.9$ and $\left.10.1 \mathrm{~Hz}, \mathrm{H}-3^{\prime}\right), 6.19(1 \mathrm{H}$, dd q, $J=15.0,10.0$ and $\left.1.8 \mathrm{~Hz}, \mathrm{H}-5^{\prime}\right), 5.87\left(1 \mathrm{H}, \mathrm{dq}, J=15.0\right.$ and $\left.7.0 \mathrm{~Hz}, \mathrm{H}-6^{\prime}\right)$, $4.681 \mathrm{H}$, br dd, $J=17.2$ and $3.1 \mathrm{~Hz}, \mathrm{H}-1 \mathrm{a}), 4.34(1 \mathrm{H}$, ddd, $J=17.2,3.8$ and $3.0 \mathrm{~Hz}, \mathrm{H}-1 \mathrm{~b}), 3.95(1 \mathrm{H}, \mathrm{br}$ signal, $\mathrm{OH}-17), 3.8-3.6\left(3 \mathrm{H}, \mathrm{m}, \mathrm{H}_{2}-17\right.$ and $\left.\mathrm{H}-3\right), 2.93$ $(1 \mathrm{H}, \mathrm{m}, \mathrm{H}-4 \mathrm{a}), 2.78(1 \mathrm{H}$, br ddd, $J=17.6,3.1$, and 3.0 $\mathrm{Hz}, \mathrm{H}-4 \mathrm{~b}, 1.84\left(3 \mathrm{H}, \mathrm{s}, \mathrm{H}_{3}-16\right), 1.79(3 \mathrm{H}, \mathrm{dd}, J=7.0$ and $\left.1.8 \mathrm{~Hz}, \mathrm{H}_{3}-7^{\prime}\right) .{ }^{13} \mathrm{C}$ DMSO- $d_{6}(\delta / \mathrm{ppm}): 196.71$ (S, C-9), 164.21 (S, C-11), 157.78, 146.84, 146.50, $144.94(4 \times \mathrm{S}$, C-5, -7, -13, -15), 135.44, 134.21, 131.88. 131.50, 130.51, $124.24\left(6 \times \mathrm{D}, \mathrm{C}-1^{\prime},-2^{\prime},-3^{\prime},-4^{\prime},-5^{\prime},-6^{\prime}\right), 130.51,117.72$, 109.03 (3×s, C-6, -10, -12), 119.19 (D, C-14), 84.79 (S, C-8), 74.21 (D, C-3), 63.77 (2×T, C-1, -17), 32.04 (T, C-4), 28.78 (Q, C-16), 18.18 (Q, C-7').

2: $\mathrm{M}^{+}, m / z$ 478; anal. C, $67.61 \%$; $\mathrm{H}, 5.39 \%$, calcd for $\mathrm{C}_{27} \mathrm{H}_{26} \mathrm{O}_{8}, \mathrm{C}, 67.77 \%$; H, 5.48\%; ${ }^{13} \mathrm{C}$ NMR DMSO- $d_{6}$ $(\delta / \mathrm{ppm}): 194.47$ (S, C-9), 170.96 and $168.32(2 \times \mathrm{S}$, $\left.2 \times \mathrm{CH}_{3} \mathrm{CO}_{2}\right), 164.65(\mathrm{~S}, \mathrm{C}-11), 154.62,147.46,144.71$, $142.68(4 \times \mathrm{S}, \mathrm{C}-5,-7,-13,-15), 137.88,137.35,133.80$. $131.34,129.02,127.04\left(6 \times \mathrm{D}, \mathrm{C}-1^{\prime},-2^{\prime},-3^{\prime},-4^{\prime},-5^{\prime},-6^{\prime}\right)$, 130.41, 122.57, 115.48 (3×S, C-6, -10, -12), 123.67 (Dd, ${ }^{1} J=163.5$ and $\left.{ }^{3} J=5.5 \mathrm{~Hz}, \mathrm{C}-14\right), 85.28\left(\mathrm{Sq},{ }^{2} J=4.5 \mathrm{~Hz}\right.$, C-8), 71.49 (D, C-3), 65.79 and $64.81(2 \times \mathrm{T}, \mathrm{C}-1,-17)$, 32.43 (T, C-4), 27.51 (Q, C-16), 20.81 and $20.58(2 \times \mathrm{Q}$, $\left.2 \times \mathrm{CH}_{3} \mathrm{CO}_{2}\right), 18.51\left(\mathrm{Q}, \mathrm{C}-7^{\prime}\right)$. Selected NOE experiments $\left(\mathrm{CDCl}_{3}\right):\{\mathrm{H}-3\}$ enhanced $\mathrm{H}-1 \mathrm{~b}(3.5 \%), \mathrm{H}_{3}-16(0.5 \%)$, $\mathrm{H}_{2}-17(2 \%) ; \quad\{\mathrm{H}-4 \mathrm{a}\}$ enhanced $\mathrm{H}-1^{\prime}(5 \%) ;\{\mathrm{H}-4 \mathrm{~b}\}$ enhanced $\mathrm{H}-3 \quad(1.5 \%)$ and $\mathrm{H}-1^{\prime} \quad(2.5 \%) ; \quad\{\mathrm{H}-14\}$ enhanced $\mathrm{H}-2^{\prime}(14 \%) ;\left\{\mathrm{H}_{3}-16\right\}$ enhanced $\mathrm{H}-1 \mathrm{~b}(1 \%)$ and $\mathrm{H}-3 \quad(1 \%) \quad\left\{\mathrm{H}-1^{\prime}\right\}$ enhanced $\mathrm{H}_{2}-4 \quad(1.5 \%)$ and $\mathrm{H}-3^{\prime}$ $(3.5 \%)$.

3: $\mathrm{mp} 142-145^{\circ} \mathrm{C} ; \mathrm{M}^{+}, m / z$ 408. ${ }^{1} \mathrm{H}$ NMR acetone- $d_{6}$ $(\delta / \mathrm{ppm}): 7.26\left(1 \mathrm{H}\right.$, br d, $\left.J=15.3 \mathrm{~Hz}, \mathrm{H}-1^{\prime}\right), 7.16(1 \mathrm{H}, \mathrm{s}$, $\mathrm{H}-14), 6.88\left(1 \mathrm{H}, \mathrm{m}, \mathrm{H}-2^{\prime}\right), 6.46\left(1 \mathrm{H}, \mathrm{m}, \mathrm{H}-4^{\prime}\right), 6.40(1 \mathrm{H}$, $\left.\mathrm{m}, \mathrm{H}-3^{\prime}\right), 6.21\left(1 \mathrm{H}, \mathrm{m}, \mathrm{H}-5^{\prime}\right), 5.89\left(1 \mathrm{H}, \mathrm{m}, \mathrm{H}-6^{\prime}\right), 4.68$ and $4.36\left(2 \mathrm{H}\right.$, br d, $\left.J=17.2 \mathrm{~Hz}, \mathrm{H}_{2}-1\right), 4.05(3 \mathrm{H}, \mathrm{s}$, 13-OMe), $4.00(1 \mathrm{H}$, br signal, $\mathrm{OH}-17), 3.8-3.6(3 \mathrm{H}, \mathrm{m}$, $\mathrm{H}_{2}-17$ and $\left.\mathrm{H}-3\right), 2.90$ and $2.80\left(2 \mathrm{H}, \mathrm{m}, \mathrm{H}_{2}-4\right), 1.85(3 \mathrm{H}$, $\left.\mathrm{s}, \mathrm{H}_{3}-16\right), 1.80\left(3 \mathrm{H}, \mathrm{dd}, J=7.0\right.$ and $\left.1.8 \mathrm{~Hz}, \mathrm{H}_{3}-7^{\prime}\right)$. \{13-OMe\} enhanced $\mathrm{H}-14(15 \%)$.

4: $\operatorname{mp} 92-95^{\circ} \mathrm{C} ;[\alpha]_{\mathrm{D}}=335(c \quad 0.2, \mathrm{MeOH}) ; \mathrm{UV} \lambda_{\max }$ 250sh and $320(\varepsilon 10600$ and 8900$) ;{ }^{1} \mathrm{H}$ NMR $\mathrm{CDCl}_{3}$ $(\delta / \mathrm{ppm}): 6.73(1 \mathrm{H}, \mathrm{s}, \mathrm{H}-14), 4.86(1 \mathrm{H}, \mathrm{ddd}, J=17.5,2.9$ and $1.1 \mathrm{~Hz}, \mathrm{H}-1 \mathrm{a}), 4.40(1 \mathrm{H}$, ddd, $J=17.5,3.8$ and 3.1 $\mathrm{Hz}, \mathrm{H}-1 \mathrm{~b}), 3.95-3.65\left(3 \mathrm{H}, \mathrm{m}, \mathrm{H}_{2}-17\right.$ and $\left.\mathrm{H}-3\right), 3.15-$ $2.55\left(4 \mathrm{H}, \mathrm{m}, \mathrm{H}_{2}-4\right.$ and $\left.-1^{\prime}\right), 2.50(1 \mathrm{H}$, br signals, OH17), $1.88\left(3 \mathrm{H}, \mathrm{s}, \mathrm{H}_{3}-16\right), 1.7-1.1\left(10 \mathrm{H}, \mathrm{m}, \mathrm{H}_{2}-2^{\prime},-3^{\prime},-4^{\prime}\right.$, $\left.-5^{\prime},-6^{\prime}\right), 0.90\left(3 \mathrm{H}, \mathrm{t}, J=6.0 \mathrm{~Hz}, \mathrm{H}_{3}-7^{\prime}\right)$.

5: oil, $\mathbf{M}^{+}, m / z$ 484; ${ }^{1} \mathrm{H}$ NMR $\mathrm{CDCl}_{3}$ ( $\left.\delta / \mathrm{ppm}\right): 7.01$ $(1 \mathrm{H}, \mathrm{s}, \mathrm{H}-14), 4.85$ and $4.42(2 \mathrm{H}$, br d, $J=17.5 \mathrm{~Hz}$, $\left.\mathrm{H}_{2}-1\right), 4.33$ and $4.30\left(2 \mathrm{H}, \mathrm{m}, \mathrm{H}_{2}-17\right), 3.90(1 \mathrm{H}, \mathrm{m}, \mathrm{H}-3)$, 3.15-2.55 (4H, m, $\mathrm{H}_{2}-4$ and $\left.-1^{\prime}\right), 2.37(3 \mathrm{H}, \mathrm{s}, 13-\mathrm{OAc})$, $2.13(3 \mathrm{H}, \mathrm{s}, 17-\mathrm{OAc}), 1.87\left(3 \mathrm{H}, \mathrm{s}, \mathrm{H}_{3}-16\right), 1.8-1.1(10 \mathrm{H}$, $\left.\mathrm{m},-2^{\prime},-3^{\prime},-4^{\prime},-5^{\prime},-6^{\prime}\right), 0.89\left(3 \mathrm{H}, \mathrm{t}, J=6.0 \mathrm{~Hz}, \mathrm{H}_{3}-7^{\prime}\right)$. 
6: 1 +dioxane $/ \mathrm{OsO}_{4} / \mathrm{KIO}_{4} / \mathrm{rt} 10 \mathrm{~min} ; \mathrm{M}^{+}, m / z$ 330, 312 $\left(\mathrm{M}^{+}-18\right)\left(312.0710\right.$ calcd for $\left.\mathrm{C}_{17} \mathrm{H}_{12} \mathrm{O}_{6} 312.0634\right) ; \lambda_{\max }$ $320 \mathrm{~nm}\left(\varepsilon\right.$ 8900). ${ }^{1} \mathrm{H}$ NMR acetone- $d_{6}(\delta / \mathrm{ppm}): 10.72$ $\left(1 \mathrm{H}, \mathrm{s}, \mathrm{H}-1^{\prime}\right), 7.37(1 \mathrm{H}, \mathrm{s}, \mathrm{H}-14), 5.00(1 \mathrm{H}$, br signal, $\mathrm{OH}-17), 4.74$ and $4.40\left(2 \mathrm{H}\right.$, br d, $\left.J=17.5 \mathrm{~Hz}, \mathrm{H}_{2}-1\right)$, 4.0-3.4 $\left(3 \mathrm{H}, \mathrm{m}, \mathrm{H}_{2}-17\right.$ and $\left.\mathrm{H}-3\right), 2.95$ and $2.90(2 \mathrm{H}, \mathrm{m}$, $\left.\mathrm{H}_{2}-4\right), 1.90\left(3 \mathrm{H}, \mathrm{s}, \mathrm{H}_{3}-16\right)$.

7: $\mathrm{M}^{+}, m / z$ 352; anal. $\mathrm{C}, 74.78 \%$; $\mathrm{H}, 6.67 \%$, calcd for $\mathrm{C}_{22} \mathrm{H}_{24} \mathrm{O}_{4}, \mathrm{C}, 74.97 \%$; $\mathrm{H}, 6.86 \%$; the ${ }^{1} \mathrm{H}$ NMR spectrum is in Table 1 .

8: oil, $\mathrm{M}^{+}, m / z$ 360(20\%), $261\left(\mathrm{M}^{+}-99\right)$ (100), 233(38). ${ }^{1} \mathrm{H}$ NMR $\mathrm{CDCl}_{3}(\delta / \mathrm{ppm}): 5.10(1 \mathrm{H}$, br signal, OH-9), 5.05 and $4.72\left(2 \mathrm{H}\right.$, br d, $\left.J=15.4 \mathrm{~Hz}, \mathrm{H}_{2}-1\right), 3.9-3.7$ $\left(3 \mathrm{H}, \mathrm{m}, \mathrm{H}_{2}-16\right.$ and $\left.\mathrm{H}-3\right), 3.54$ and $3.39(2 \mathrm{H}, \mathrm{d}, J=21.7$ $\left.\mathrm{Hz}, \mathrm{H}_{2}-11\right), 3.25(1 \mathrm{H}, \mathrm{m}, \mathrm{H}-14), 2.73(1 \mathrm{H}, \mathrm{dd}, J=15.2$ and $2.6 \mathrm{~Hz}, \mathrm{H}-13 \mathrm{a}), 2.69$ and $2.60\left(2 \mathrm{H}, \mathrm{m}, \mathrm{H}_{2}-4\right), 2.58$ $(1 \mathrm{H}, \mathrm{dd}, J=15.2$ and $5.5 \mathrm{~Hz}, \mathrm{H}-13 \mathrm{~b}), 2.50(1 \mathrm{H}, \mathrm{br}$ signal, $\mathrm{OH}-16), 2.08\left(3 \mathrm{H}, \mathrm{s}, \mathrm{H}_{3}-15\right), 1.5-1.1(12 \mathrm{H}, \mathrm{m}$, $\left.\mathrm{H}_{2}-1^{\prime}-6^{\prime}\right), 0.86\left(3 \mathrm{H}, \mathrm{t}, J=6.2 \mathrm{~Hz}, \mathrm{H}_{3}-7^{\prime}\right) .{ }^{13} \mathrm{C}$ NMR $\mathrm{CDCl}_{3}(\delta / \mathrm{ppm}): 210.65$ (S, C-12), 148.03, 131.38, $130.30,128.33,120.71,118.4(6 \times \mathrm{S}, \mathrm{ArC}), 75.00$ (D, C-3), 65.79 and $64.93(2 \times \mathrm{T}, \mathrm{C}-1,-16), 43.23,41.42$, $34.78,31.82,29.50,29.14,27.24,26.80,22.63(9 \times \mathrm{T}, \mathrm{C}-4$, $\left.-11,-13,-1^{\prime},-2^{\prime},-3^{\prime},-4^{\prime},-5^{\prime},-6^{\prime}\right), 34.86$ (D, C-14), 14.09 $\left(\mathrm{Q}, \mathrm{C}-7^{\prime}\right), 11.02(\mathrm{Q}, \mathrm{C}-15)$. Selected NOE experiments $\left(\mathrm{CDCl}_{3}\right):\left\{\mathrm{H}_{2}-11\right\}$ enhanced $\mathrm{H}_{3}-15(0.5 \%) ;\left\{\mathrm{H}_{3}-15\right\}$ enhanced $\mathrm{H}_{2}-11(3.5 \%)$.

\section{References}

1. Arnone, A.; Assante, G.; Nasini, G.; Strada, S.; Vercesi, A. J. Nat. Prod. 2002, in press.

2. Arnone, A.; Nasini, G.; Vajna de Pava, O. Phytochemistry 1998, 48, 507-510 and references cited therein.

3. Strain IPV 166, belonging to the Mycological Collection of 'Istituto di Patologia Vegetale, Università di Milano'.

4. Merlini, L.; Mondelli, R.; Nasini, G.; Hesse, M. Helv. Chim. Acta 1973, 56, 232-239.

5. Takahashi, M.; Koyama, K.; Netori, S. Chem. Pharm. Bull. 1990, 38, 625-628.

6. (a) Steyn, P. S.; Vleggar, R. J. Chem. Soc., Perkin 1 1976, 204-206; (b) Hashimoto, T.; Asakawa, Y. Heterocycles 1998, 47, 1067-1170.

7. Thomas, R. Chembiochem 2001, 2, 612-627.

8. Arnone, A.; Assante, G.; Nasini, G.; Vajna de Pava, O. Phytochemistry 1990, 29, 613-616. 